\title{
High-strength wall ceramics based on phosphorus slag and bentonite clay
}

\author{
Zhusupbek T. Suleimenov (iD, Aimahambet A. Sagyndykov* (iD, Zhangazy N. Moldamuratov (iD, \\ Gulsara M. Bayaliyeva (D), Zhanna B. Alimbayeva (iD) \\ M.Kh. Dulaty Taraz Regional University, Taraz, Kazakhstan \\ *Corresponding author: e-mail: ernur.abutalipov98@mail.ru
}

\begin{abstract}
Introduction. One of the promising ways to get high-strength ceramics is the method of semi-dry pressing of the "coarsely dispersed component - finely ground binder" formula. This method suggests using crushed industrial waste as the core, and finely ground nanostructured fusible clay as the binder material. Methods and materials. In the research, bentonite clay of the Darbazinsky deposit of the Turkestan region was used as plastic material, and dense crystallized phosphorus slag which is a waste of phosphorus production was used as a non-plastic coarse material. The study of the prescription factors' influence on the basic physical and mechanical properties of ceramic wall materials was carried out by the simplex method characterized as lattice planning of experiments. The nanostructure of the phosphorus slag and bentonite clay formula was studied by the electron microscopic analysis method. Results. The binder content in the amount of $25 \%$ guarantees the density of the packages, while the sintering effect becomes sufficient and the strength of the samples is $27.1 \mathrm{MPa}$. If the amount of binder increases from $25 \%$ to $40 \%$, the sintering effect continues to grow and the strength of the samples reaches $54.3 \mathrm{MPa}$. Discussion. The results show that the most active sintering effect and the dense structures forming in coarse-grained formulas with high-calcium phosphorus slag occur at $40-60 \%$ binder content. The presence of flux around slag grains in an amount of less than $30 \%$ contributes to obtaining less dense samples, with a binder content of $40 \%$, a density increase is observed, which corresponds to the mixed ceramic structures modeling. Conclusion. To get high-strength ceramic bricks, the content of coarsely dispersed components in the form of phosphorus slag with a fraction of less than $1.25 \mathrm{~mm}$ should amount to $60-70 \%$, finely ground phosphorus slag should be $5-10 \%$, and bentonite clay is to be $20-30 \%$. Optimum technological indicators are: calcination temperature $1050-1100^{\circ} \mathrm{C}$, pressing pressure $20-25 \mathrm{MPa}$, press powder moisture content $7-8 \%$.
\end{abstract}

KEYWORDS: phosphorus slag, bentonite clay, nanostructure, semi-dry pressing, pressing powder.

FOR CITATION: Suleimenov Zh.T., Sagyndykov A.A., Moldamuratov Zh.N., Bayaliyeva G.M., Alimbayeva Zh.B. High-strength wall ceramics based on phosphorus slag and bentonite clay. Nanotechnologies in Construction. 2022; 14(1): 11 -17. https://doi.org/10.15828/20758545-2022-14-1-11-17.

\section{INTRODUCTION}

$\mathrm{O}$ ne of the promising building materials with a variety of colors, textures, and shapes that can develop the quality of building cladding and improve the architectural appearance of buildings is ceramic brick [1-3].

In Kazakhstan, the demand for high-quality ceramic products, such as clinker, the facade facing bricks is increasing. The limited raw material base of high-quality clay raw materials hampers the production of the abovementioned efficient materials. The main raw materials for the ceramic bricks manufacture are loams, which are low-plastic raw materials with a short sintering interval, which does not allow obtaining high-quality bricks. The maximum strength of products made of loam, fired at a temperature of $1100^{\circ} \mathrm{C}$, does not exceed $15 \mathrm{MPa}$. In this regard, the transition to a semi-dry pressing method using industrial waste is relevant. To obtain high-strength ceramic materials, it is of interest to use "coarse component - finely ground binder" formula. With such a structure, the clay fraction consumption in the formula content will be in the range of $25-30 \%$, and $75-100 \%$ in traditional ceramics of plastic molding [4-6].

Nowadays, the attention of ceramic building materials researchers is increasingly attracted by nanosized clay binder usage $[7,8]$.

(c) Suleimenov Zh.T., Sagyndykov A.A., Moldamuratov Zh.N., Bayaliyeva G.M., Alimbayeva Zh.B., 2022 

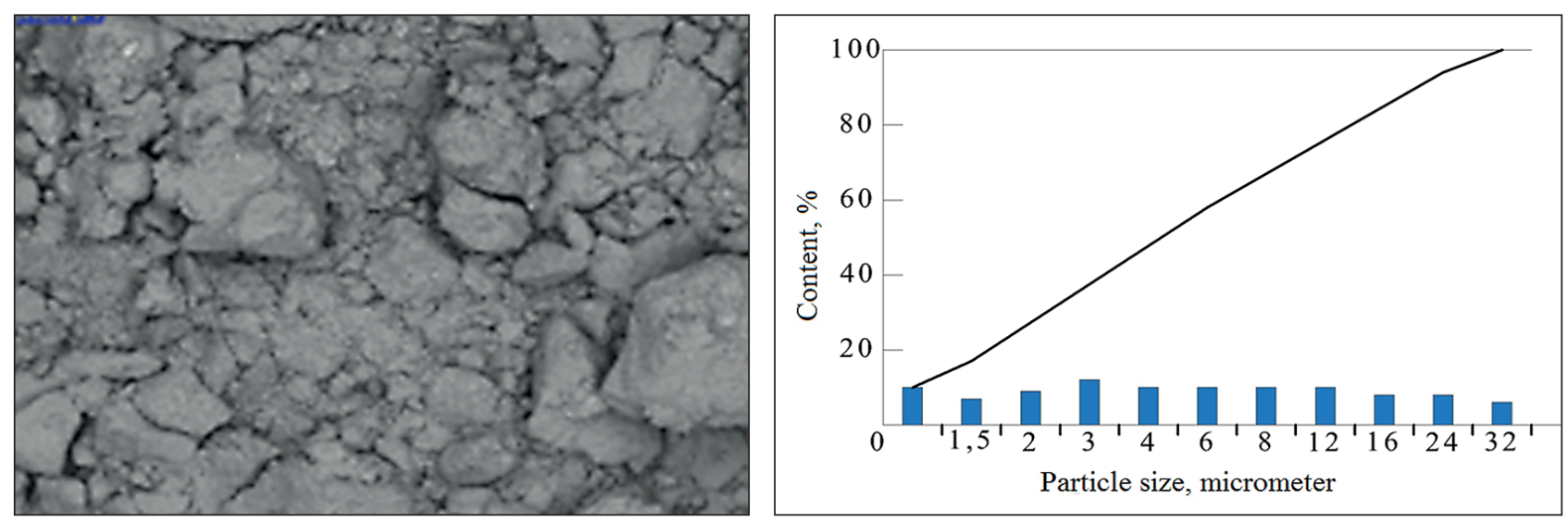

Fig. 1. Micrograph $(a, \times 100)$ and size distribution of bentonite clay particles $(b)$ :

- - distribution by fractions; — - cumulative distribution

\section{METHODS AND MATERIALS}

Bentonite clay of the Darbazinsky deposit of the Turkestan region was used as a plastic material for the studied ceramic masses, and dense crystallized phosphorus slag was used as a coarse material.

Bentonite is a nanostructured material with a high specific surface area, which has the property of self-dispersion, which helps to bind a large amount of non-plastic material. It is well known that the clay mineral montmorillonite consists of three store packages. Crushed particles of the phosphorus slag, located in the interpacket layer of montmorillonite form strong structures $[4,6,8,9]$.

Determination of the granulometric composition of bentonite (Fig. 1) showed that the highly dispersed powder is equally distributed over fractions from 1 to $32 \mathrm{mi}-$ crometers, with a predominant distribution in the range from 1 to 12 micrometers. Particles form aggregates of irregular shape [10].

Table 1 shows the chemical composition of clay and phosphorus slag.

The slag is characterized by a high content of calcium oxide (47.5\%), as well as the phosphorus pentoxide presence and fluorine compounds up to $4.1 \%$, which have a fluxing effect and help to reduce the calcination temperature of ceramic materials. In addition to basic oxides of silicon, aluminium, and iron, clay contains low-melting oxides such as $\mathrm{CaO}, \mathrm{MgO}, \mathrm{Na}_{2} \mathrm{O}$ and $\mathrm{K}_{2} \mathrm{O}$ [11-13].

According to the number of plasticities (38-40), clay belongs to highly plastic, according to the content of clay particles (62.5\%) to highly dispersed, according to the index of refractoriness to fusible clays $\left(1250^{\circ} \mathrm{C}\right)$.

The phase composition of bentonite clay is characterized by the quartz $(d=0.335 ; 0.425 \mathrm{~nm})$, illite $(d=0.319$; $0.256 \mathrm{~nm})$, biotite $(d=1.000 ; 0.353 \mathrm{~nm})$, montmorillonite $(d=0.950 ; 0.225 \mathrm{~nm})$, kaolinite $(d=0.709 \mathrm{~nm})$ presence. Carbonate inclusions are represented by calcite $(d=0,303 ; 0.228 \mathrm{~nm})$. Potassium feldspar and ferritic phases are also present. The content of montmorillonite is $80-85 \%$ [14-16].

Phosphorus slag from the Taraz phosphorus plant is a dense, crystallized mass that melts at a temperature of $1320-1350^{\circ} \mathrm{C}$. The phase composition of phosphorus slag is represented mainly by wollastonite and cuspidin [17, 18].

Samples of wall ceramic bricks were made as follows. The slag was subjected to crushing and screening through a $1.25 \mathrm{~mm}$ sieve. To obtain a binder, slag and clay were subjected to grinding in a ball mill until they completely passed through a $0.063 \mathrm{~mm}$ sieve. Slag granules less than $1.25 \mathrm{~mm}$ in size were subjected to moisture until a moisture content of $8 \%$ was reached, then a binder was applied

\section{Table 1}

Chemical composition of raw materials

\begin{tabular}{|l|c|c|c|c|c|c|c|c|c|c|}
\hline \multirow{2}{*}{ Raw material } & \multicolumn{7}{|c|}{ Composition, mass. \% } \\
\cline { 2 - 11 } & $\mathbf{S i O}_{2}$ & $\mathbf{A l}_{2} \mathbf{O}_{3}$ & $\mathbf{F e}_{2} \mathbf{O}_{3}$ & $\mathbf{C a O}$ & $\mathbf{M g O}$ & $\mathbf{N a}_{2} \mathbf{O}$ & $\mathbf{K}_{2} \mathbf{O}$ & $\mathbf{S O}_{3}$ & $\begin{array}{c}\mathbf{F}+ \\
\mathbf{P}_{2} \mathbf{O}_{5}\end{array}$ & $\begin{array}{c}\text { calcination } \\
\text { losses }\end{array}$ \\
\hline $\begin{array}{l}\text { Bentonite } \\
\text { Clay }\end{array}$ & 60.51 & 16.06 & 6.43 & 1.27 & 2.23 & 2.41 & 2.8 & 1.3 & - & 8.7 \\
\hline $\begin{array}{l}\text { Phosphorus } \\
\text { slag }\end{array}$ & 41.3 & 2.8 & 0.4 & 47.5 & 1.2 & 0.3 & 0.1 & 0.6 & 4.1 & 0.2 \\
\hline
\end{tabular}


to their surface. The prepared press powder was poured into a mold and subjected to pressing at a pressure of $15-25 \mathrm{MPa}$. The strength of the molded raw material is 0.35-0.4 MPa, which satisfies the requirements of the automatic stacker. The sintering process of the composition was studied on cubes samples of $50 \times 50 \times 50 \mathrm{~mm}$ in size. Samples were dried at a maximum temperature of $105^{\circ} \mathrm{C}$ for 3 hours; calcination was carried out in an electric muffle furnace at a temperature of $1050-1100^{\circ} \mathrm{C}$ with an isothermal exposure of $30 \mathrm{~min}$ [19-21].

In order to determine the optimal ratio of the core and the shell, the structures were modeled at a ratio of 5,10 , 20. The amount of the shell substance varied from 20 to $50 \%$. The size of the core aggregates was changed from 0.5 to $1.25 \mathrm{~mm}$, the thickness of the shell was changed from 0.05 to $0.3 \mathrm{~mm}$. The strongest structures were obtained at a ratio of their sizes equal to $10-20$.

In the technology of semi-dry pressing, it is important to establish the maximum grain sizes of the coarsely dispersed component. To do this, the temperature stresses at the grain boundaries were calculated according to the formula of W.D. Kingery [7]:

$$
\sigma=\frac{1}{3} \cdot \frac{\left(\frac{V_{1} E_{1}}{1-\mu_{1}}\right) \cdot\left(\frac{V_{2} E_{2}}{1-\mu_{2}}\right)}{\left(\frac{V_{1} E_{1}}{1-\mu_{1}}\right) \cdot\left(\frac{V_{2} E_{2}}{1-\mu_{2}}\right)} \cdot \Delta \alpha \cdot \Delta T \cdot d,
$$

where: $\sigma-$ stress in the contact layer, $\mathrm{MPa} ; E_{1}$ and $E_{2}-$ moduli of elasticity, $\mathrm{MPa} ; \mu_{1}, \mu_{2}-$ Poisson's ratios; $\Delta \alpha$ is the difference in the temperature coefficient of the linear expansion of the phases; $\Delta \mathrm{T}$ is the temperature interval in which stresses arise; $d$ - grain size; $V$ - are the volume fractions of the contacting phases.

From the analysis of changes in the thermal stresses developing at the grain boundaries, the maximum sizes of slag grains $(1.25 \mathrm{~mm})$ were selected.

Studies of the microstructure of ceramic samples were carried out on a JEOL JSM7500 scanning electron microscope with an X-ray spectral analysis attachment [20].

\section{RESULTS}

The influence study of recipe factors on the basic physical and mechanical properties of ceramic wall materials was carried out by the simplex-lattice planning of experiments using the properties of an incomplete cubic form model as a mathematical model [21]:

$$
\begin{aligned}
& Y=A_{1}+A_{2}+A_{3}+A_{4} x y+A_{5} x z+A_{6} y z+ \\
& +A_{7} x y z+A_{8} x y(x-y)+A_{9} x z(x-z)+A_{10} y z(y-z) .
\end{aligned}
$$

The ultimate compressive $\left(\mathrm{R}_{\text {com }}\right)$ and bending strength $\left(\mathrm{R}_{\text {bend }}\right)$, shrinkage $(\mathrm{U}, \%)$, and water absorption $(\mathrm{W}, \%)$ were studied as $\mathrm{Y}$ response functions.

The followings were used as raw materials for the ceramic bricks production:

$X_{1}$ - the content of phosphorus slag fraction less than $1.25 \mathrm{~mm}, 55-70 \%$;

$X_{2}-$ the content of finely ground bentonite clay, 25-40\%;

$X_{3}-$ the content of finely ground phosphorus slag, $5-20 \%$.

The experiment planning matrix is given in the Table 2 .

\begin{tabular}{|c|c|c|c|c|c|c|c|}
\hline \multirow{3}{*}{$\begin{array}{c}\text { Composition } \\
\text { number }\end{array}$} & \multicolumn{3}{|c|}{ Content of components, $\%$} & \multicolumn{4}{|c|}{ Properties } \\
\hline & $\begin{array}{l}\text { Phosphorus slag } \\
\text { fraction less than } \\
1.25 \mathrm{~mm}, \%\end{array}$ & Bentonite clay, $\%$ & $\begin{array}{c}\text { Finely ground } \\
\text { phosphorus slag, } \\
\%\end{array}$ & \multirow[t]{2}{*}{$\mathrm{U}, \%$} & \multirow[t]{2}{*}{$\begin{array}{l}\text { Rcom, } \\
\text { MPa }\end{array}$} & \multirow[t]{2}{*}{$\begin{array}{l}\text { Rbend, } \\
\text { MPa }\end{array}$} & \multirow[t]{2}{*}{$\mathrm{W}, \%$} \\
\hline & $X_{1}$ & $X_{2}$ & $X_{3}$ & & & & \\
\hline 1 & 70 & 25 & 5 & 0.9 & 26.1 & 2.8 & 13.8 \\
\hline 2 & 55 & 40 & 5 & 1.9 & 54.3 & 4.7 & 5.2 \\
\hline 3 & 55 & 25 & 20 & 1.6 & 36.7 & 3.6 & 8.2 \\
\hline 4 & 65 & 30 & 5 & 1.2 & 32.3 & 3.4 & 11.8 \\
\hline 5 & 60 & 35 & 5 & 1.6 & 51.5 & 3.7 & 10.4 \\
\hline 6 & 65 & 25 & 10 & 1.4 & 30.8 & 3.2 & 11.8 \\
\hline 7 & 60 & 25 & 15 & 1.5 & 34.7 & 3.7 & 11.2 \\
\hline 8 & 55 & 35 & 10 & 1.1 & 45.3 & 3.6 & 7.4 \\
\hline 9 & 55 & 30 & 15 & 1.2 & 38.6 & 3.7 & 8.6 \\
\hline 10 & 60 & 30 & 10 & 1.4 & 43.4 & 3.9 & 10.9 \\
\hline
\end{tabular}

\section{Table 2}

\section{Experiment Design Matrix}




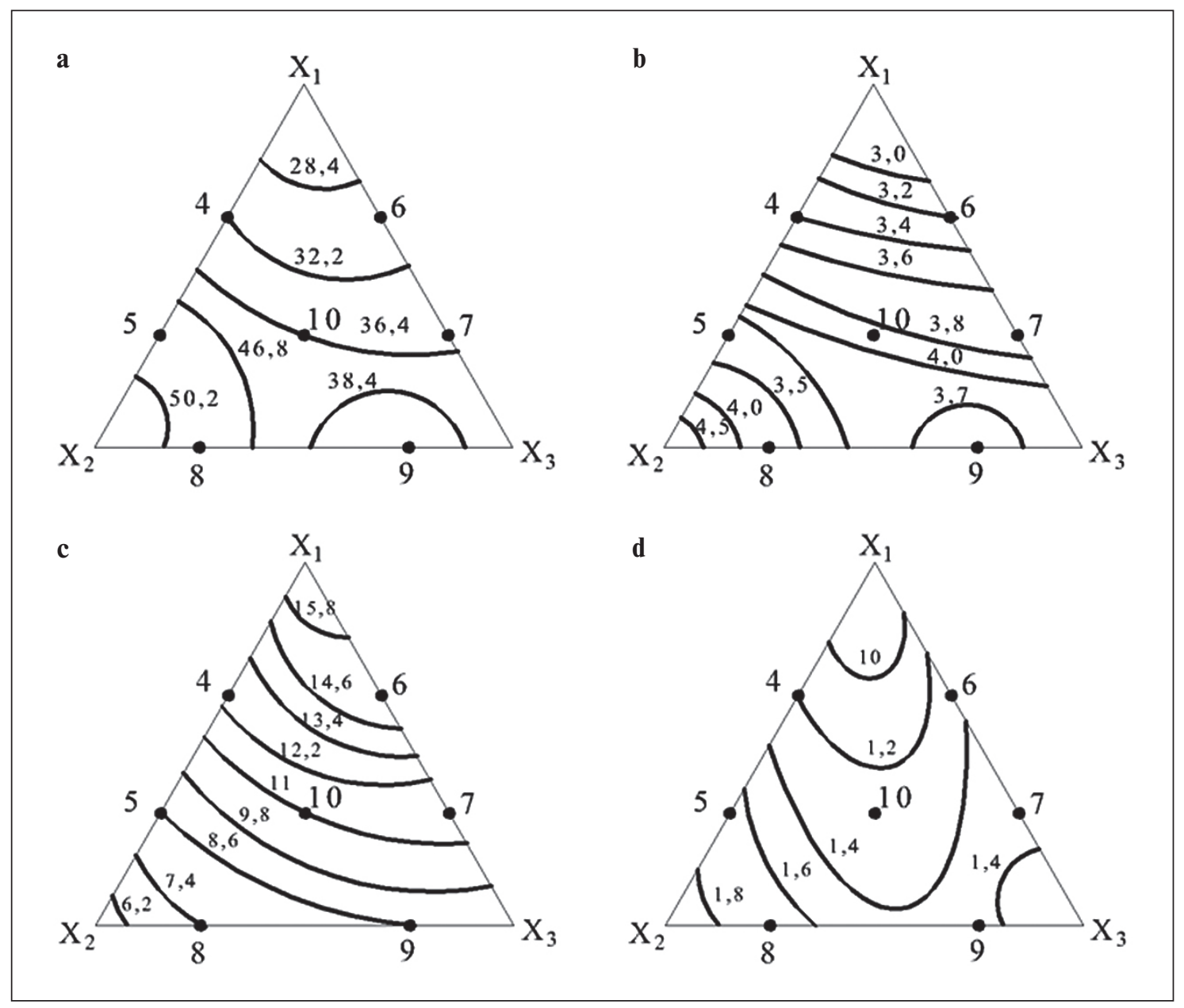

Fig. 2. Equal values lines of high-strength ceramics properties changes:

$\mathrm{a}$ - compressive strength; $\mathrm{b}$ - bending strength; $\mathrm{c}$ - water absorption; $\mathrm{d}$ - shrinkage

The figurative points of the binder compositions based on slag and clay are in the $\mathrm{CaO}-\mathrm{Al}_{2} \mathrm{O}_{3}-\mathrm{SiO}_{2}$ state diagram and are located in the anorthite-wollastonite-quartz triangle with eutectic at a temperature of $1165^{\circ} \mathrm{C}$.

The regression equation of the compressive strength dependence of ceramic bricks on the composition of the charge has the form:

$$
\begin{aligned}
& R_{c}=27,1 x_{1}+54,3 x_{2}+49,7 x_{3}-17,1 x_{1} x_{2}+ \\
& +18,225 x_{1} x_{3}-61,875 x_{2} x_{3}+315 x_{1} x_{2}\left(x_{1}-x_{2}\right)+ \\
& +400,275 x_{1} x_{3}\left(x_{1}-x_{3}\right)+282,375 x_{2} x_{3}\left(x_{2}-x_{3}\right)+ \\
& +228,15 x_{1} x_{2} x_{3} .
\end{aligned}
$$

The clay content in the amount of $25 \%$ guarantees the packing density, the sintering effect becomes sufficient, and the samples strength is $27.1 \mathrm{MPa}$ (Fig. 1, b). If the clay amount increases from $25 \%$ to $40 \%$, the sintering effect continues to grow and the samples strength reaches 54.3 MPa.

According to the obtained "composition-property" diagrams (Fig. 2, a, b, c, d), ceramic bricks have low shrinkage (0.9-1.6\%), water absorption (7.4-12.1\%), high bending strength index (2.8-4.7 MPa).

\section{DISCUSSION}

The obtained results show that the most active sintering and dense structures formation in coarse-grained formulas with high-calcium slag occur at a binder content of 35-45\% and core-to-shell ratios of 10-20 in accordance with the mixed ceramic structures modeling [17-19].

According to thermodynamic calculations, the most likely anortite $\left(\mathrm{CaO} \mathrm{Al}_{2} \mathrm{O}_{3} 2 \mathrm{SiO}_{2}\right)$, quartz, and wollastonite formation is in the calcination process at temperatures of 400,800 , and $1000^{\circ} \mathrm{C}$; such phases with the largest negative values of the Gibss free energy $(\Delta Z)$, with densities that do not change during the synthesis process and contribute to the increase in the brick strength.

The frame structure creation was ensured through the use of a polyfractional composition (phosphorus slag) and finely ground bentonite and phosphorus slag binder. 

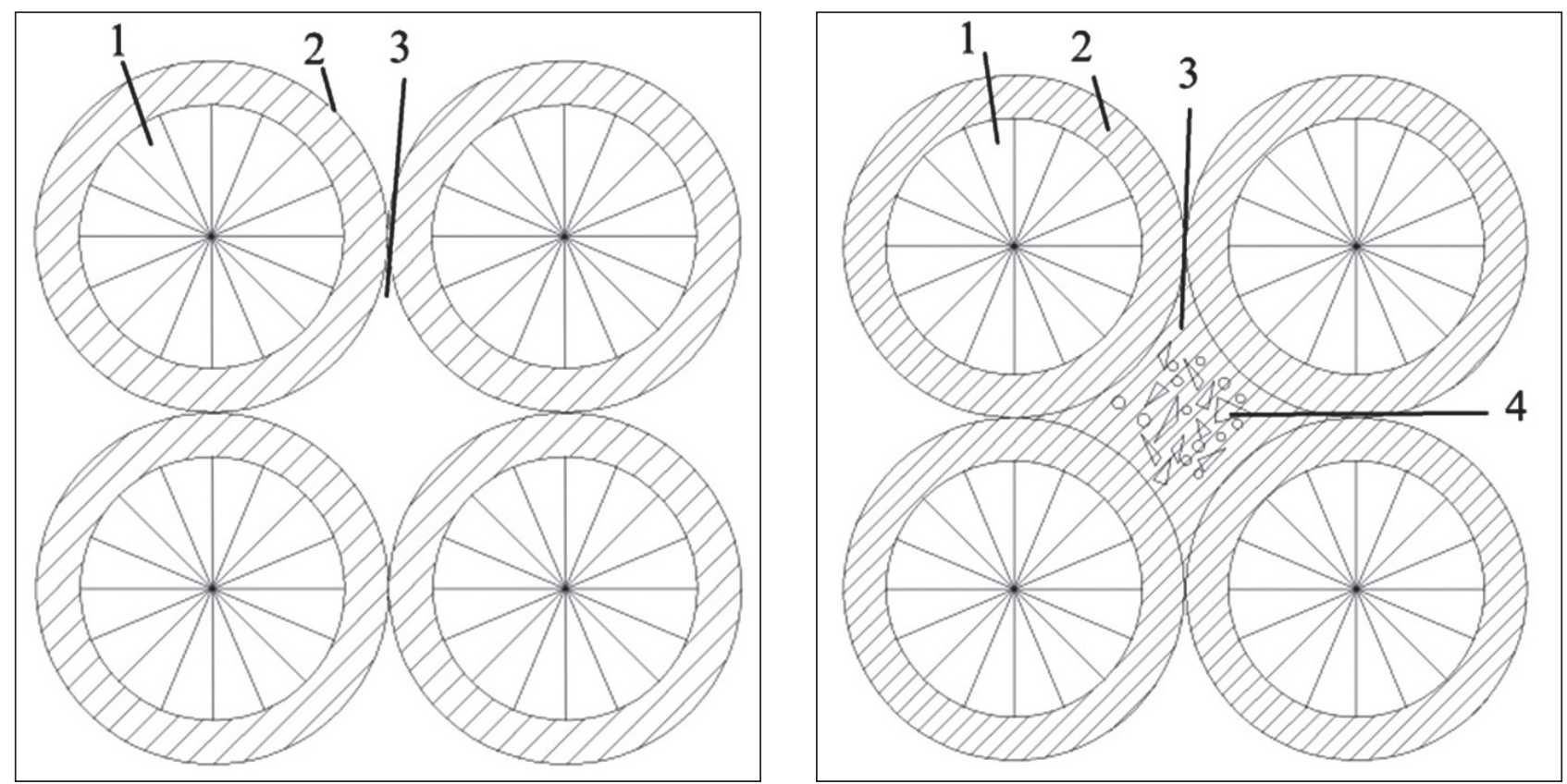

Fig. 3. Frame structure model of ceramic materials according to the "core - shell" type: 1 - slag granule; 2 - binder; 3 - pores; 4 - binder and wollastonite and anorthite crystals

Figure 3 shows frame structure models of the material constituent elements (crystal frame and binder).

The samples structure from the granular slag with binders formula is the most pronounced variant of "core - shell" type structures (Fig. 4, a, b). And the nature of slag with binders structures most clearly reflects the process of their formation. It can be seen from the structure of the samples that the binder forms shells not only around large grains but also around medium and small slag grains located between them. It may be viewed that the shells interact with the surface of the grains to form the crystalline phases of wollastonite and anorthite. The shell and grain interaction proceeds very actively. As a result of this interaction, a fairly noticeable transition zone is formed from the slag grain surface to the shell. The transition zone formation determines the slag grain and the shell consistency. Therefore, the samples strength is high and amounts to $49-54.3 \mathrm{MPa}$ in compression and 4.3-4.7 MPa in bending [15].

From the structure of the densely sintered samples, achieved by using the maximum (40\%) amount of clay in the binder and after calcination at a high temperature
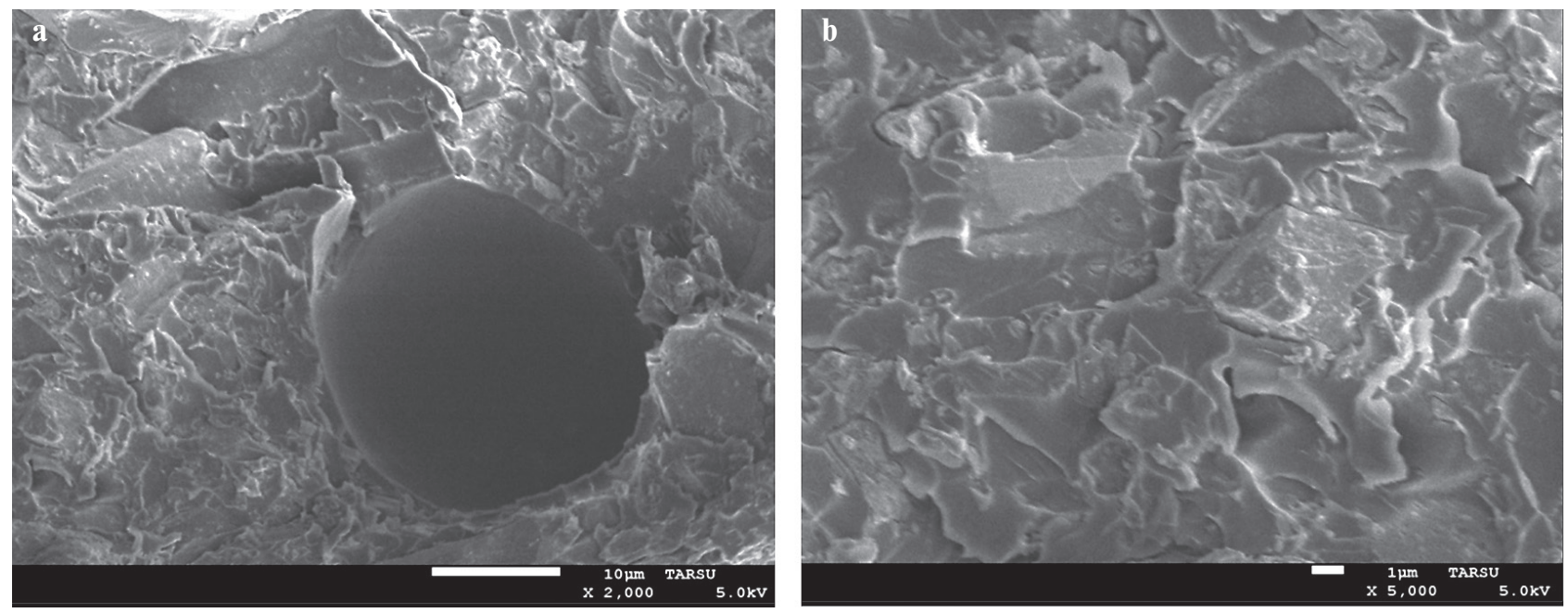

Fig. 4. Ceramics microstructure from the phosphorus slag and bentonite clay composition: $\mathrm{a}-$ calcination temperature $1050^{\circ} \mathrm{C} ; \mathrm{b}-$ calcination temperature $1100^{\circ} \mathrm{C}$ 
$\left(1050-1100^{\circ} \mathrm{C}\right)$, it is seen that the smallest slag grains are involved in the liquid phase formation. The amount and reactivity of the glass phase increases due to the influence of fluorine-containing components of the slag. As a result, the thickness of the zone between the large slag grains surface and the shells grows and the crystallization of the new phases in the form of wollastonite and anorthite became active in the shell. Furthermore, glass phase viscosity decrease due to calcium ions, a growth in its penetrating ability and the glass phase affinity for slag grains contribute to its spreading over the samples' surface and the vitreous coating formation, which crystallizes upon cooling [14].
Interaction products are observed along the slag grains edges and between them, as well as on their surface.

\section{CONCLUSION}

To get high-strength ceramic bricks, the content of coarsely dispersed component in the form of phosphorus slag with a fraction of less than $1.25 \mathrm{~mm}$ should amount to $55-65 \%$, finely ground phosphorus slag should be $5-10 \%$, and bentonite clay is to be $30-40 \%$. The most favorable technological parameters are: calcination temperature $1050-1100^{\circ} \mathrm{C}$, pressing pressure $20-25 \mathrm{MPa}$, press powder moisture content $7-8 \%$.

\section{REFERENCES}

1. Suvorova O.V., Selivanova E.A., Mikhailova J.A., Masloboev V.A., Makarov D.V. Ceramic products from mining and metallurgical waste. Applied Sciences (Switzerland). 2020; 10 (10): 3515.

2. Poznyak A.I., Levitskii I.A., Barantseva S.E. Production of interior facing tiles using local raw materials. Glass and Ceramics. 2012; 69: 77-80.

3. de Figueirêdo J.M.R., Sousa Silva J.R., de Araújo Neves G., Ferreira H.C., de Lima Santana L.N. Influence of processing variables on clay-based ceramic formulations. Materials Research. 2019; 22 (3): e20180548.

4. Kadyrova Z.R., Purkhanatdinov A.P., Niyazova S.M. Research of benonite clays of Karakalpakstan for producing ceramic heat-insulating materials. New Refractories. 2020; (9): 3-5.

5. Chetverikova A.G., Kanygina O.N., Alpysbaeva G.Z., Yudin A.A., Sokabayeva S.S. Infrared spectroscopy as the method for determining structural responses of natural clays to microwave exposure. Condensed Matter and Interphases. 2019; 21 (3): 446-454.

6. Asal S., Erenturk S.A., Haciyakupoglu S. Bentonite based ceramic materials from a perspective of gamma-ray shielding: Preparation, characterization and performance evaluation. Nuclear Engineering and Technology. $2021 ; 53$ (5): 1634-1641.

7. Montayev S., Shakeshev B., Zharylgapov S. Development of a technology for producing ceramic refractory material in a composition of montmorillonite clays (bentonite-like) and ferrochrome production wastes. MATEC Web of Conferences. 2020; 315, 07007.

8. Kadyrova Z.R., Purkhanatdinov A.P., Niyazova Sh.M. Karakalpakstan Bentonite Clays - Perspective Raw Materials for Obtaining Ceramic Heat-Insulating Materials. International Journal of Innovative Technology and Exploring Engineering. 2020; 9 (8): 417-420.

9. Erdogan Y., Kok O.E. Production and characterization of nanobentonite from Sodifm bentonite with mechanical grinding. Fresenius Environmental Bulletin. 2019; 28 (11): 8141-8150.

10. Kadyrova Z.R., Purkhanatdinov A.P., Niyazova S.M. Study of Karakalpakstan Bentonite Clay for Producing Ceramic Heat-Insulating Materials. Refractories and Industrial Ceramics. 2021; 61 (5): 478-480.

11. Ngoc Lam N. Eco - Concrete made with phosphogypsum-based super sulfated cement. IOP Conference Series: Materials Science and Engineering. 2020; 869 (3), 032031.

12. Nguyen V.H., Nguyen V.C., Nguyen T.C., Tran D.M.T., Nguyen T.T.T., Vu Q.T., Nguyen D.T., Thai H. Treatment of Yellow Phosphorus Slag and Reuse of It as an Absorbent of Chromium (VI) Ions and Methylene Blue. Journal of Chemistry. 2020; (1): 1-16.

13. Garbaya H., Jraba A., Khadimallah M.A., Elaloui E. The Development of a New Phosphogypsum-Based Construction Material: A Study of the Physicochemical, Mechanical and Thermal Characteristics. Materials (Basel). 2021; 14 (23): 7369.

14. Djobo J.N.Y., Stephan D. Control of the setting reaction and strength development of slag-blended volcanic ash-based phosphate geopolymer with the addition of boric acid. Journal of the Australian Ceramic Society. 2021; 57 (4). 
15. Najimi M., Ghafoori N., Sharbaf M. Alkali-activated natural pozzolan/slag binders: Limitations and remediation. Magazine of Concrete Research. 2020; 72 (18): 919-935.

16. Sarsenbayev N.B., Kurbaniyazov S.K., Saktaganova N.A., Karshygayev R.O. The influence of additives of dehydrated clay on the properties of unburned binders and concrete on their basis. IOP Conference Series: Materials Science and Engineering. 2020; 945 (1), 012048.

17. Kenzhaliyev B.K., Surkova T.Y., Abdikerim B.E., Berkinbayeva A.N., Abikak Y.B., Yessimova D.M. Research on sorption properties of phosphoric production slag-waste. Metalurgija. 2022; 61 (1): 209-212.

18. Tian X., Zhang Y., Zhao F. Mechanism of steel slag-phosphoric acid system regulating the setting performance of phosphogypsum based building gypsum. Huagong Jinzhan/Chemical Industry and Engineering Progress. 2021; 40 (8): $4438-4444$.

19. Werner V.F., Khudyakova T.M., Sarsenbayev B.K., Kashey A.M., Sauganova G.R. Production of synthetic wollastonite based on phosphoric slag and amorphous silica produced by "solar" silicon. Materials of the International scientific and Practical online conference dedicated to the $60^{\text {h }}$ anniversary of the Doctor of Technical Sciences, Professor Sayd-Alvi Yusupovich Murtazaev. 2021; 135-138.

20. Gao P., Lu X., Yang C., Li X., Shi N., Jin S. Microstructure and pore structure of concrete mixed with superfine phosphorous slag and superplasticizer. Construction and Building Materials. 2008; 22(5): 837-840.

21. Suleimenov Z.T., Sagyndykov A.A., Kirgizbaev A.T. Ceramic Face Tiles Using Phosphoric Slags. Glass and Ceramics. 2016; 73: 62-65.

\section{INFORMATION ABOUT THE AUTHORS}

Zhusupbek T. Suleimenov - Dr. Sci. (Eng.), Academician of the National Academy of Sciences of the Republic of Kazakhstan, Professor of Construction and Materials Production Department, M.Kh. Dulaty Taraz Regional University,Taraz, Kazakhstan, ernur.abutalipov98@mail.ru, https://orcid.org/0000-0002-1431-8074

Aimahambet A. Sagyndykov - Dr. Sci. (Eng.), Professor of Construction and Materials Production Department, M.Kh. Dulaty Taraz Regional University, Taraz, Kazakhstan, ernur.abutalipov98@mail.ru, https://orcid.org/0000-0002-1812-5739

Zhangazi N. Moldamuratov - PhD, Associate Professor of Construction and Materials Production Department, M.Kh. Dulaty Taraz Regional University, Taraz, Kazakhstan, zhanga_m_n@mail.ru, https://orcid.org/0000-0002-4573-1179

Gulsara M. Bayaliyeva - Cand. Sci. (Eng.), Associate Professor of Construction and Materials Production Department, M.Kh. Dulaty Taraz Regional University, Taraz, Kazakhstan, bayali@bk.ru, https://orcid.org/0000-0002-9897-5740

Zhanna B. Alimbayeva - engineer of Construction and Materials Production Department, M.Kh. Dulaty Taraz Regional University, Taraz, Kazakhstan, alimbayeva.zhanna08@mail.ru, https://orcid.org/0000-0001-9372-4101

\section{CONTRIBUTION OF THE AUTHORS}

Suleimenov Zh.T. - scientific leadership; research concept; methodology development; scientific text editing; final results. Sagyndykov A.A. - the research concept; methodology development; experimental work carring out; experimental data processing; material accumulation; original text writing; final results.

Moldamuratov Zh.N. - original text writing; final results.

Bayalieva G.M. - experimental work carrying out; experimental data processing; original text writing; communication with the journal editors.

Alimbaeva Zh.B. - experimental work carrying out; experimental data processing; material accumulation.

\section{The authors declare no conflicts of interests.}

The article was submitted 24.01.2022; approved after reviewing 07.02.2022; accepted for publication 09.02.2022. 


\title{
Высокопрочная стеновая керамика на основе фосфорного шлака и бентонитовой глины
}

\author{
Жусупбек Таширбаевич Сулейменов (D), Аймахамбет Абуталипович Сагындыков* ID, \\ Жангазы Нуржанович Молдамуратов (D), Гульсара Муратовна Баялиева (D), Жанна Базартаевна Алимбаева (iD) \\ Таразский региональный университет имени М.Х. Дулати, Тараз, Казахстан \\ * Автор, ответственный за переписку: e-mail: ernur.abutalipov98@mail.ru
}

\begin{abstract}
АНнотАция: Введение. Одним из перспективных способов получения высокопрочной керамики является метод полусухого прессования композиции «грубодисперсный компонент - тонкоизмельченная связка» с использованием в качестве ядра дробленых отходов промышленности, связующим материалом является тонкомолотая наноструктурная легкоплавкая глина. Методы и материалы. В исследованиях в качестве пластичного материала использована бентонитовая глина Дарбазинского месторождения Туркестанской области, а непластичного грубодисперсного материала - плотный закристаллизованный фосфорный шлак - отход фосфорного производства. Изучение влияния рецептурных факторов на основные физико-механические свойства керамических стеновых материалов выполняли методом симплекс - решетчатым планированием экспериментов. Методом электронно-микроскопического анализа исследованы наноструктура композиции из фосфорного шлака и бентонитовой глины. Результаты. При содержании связки в количестве $25 \%$, гарантирующей плотность упаковок, эффект спекания становится достаточным, и прочность образцов составляет 27,1 МПа. С увеличением количества связки с 25 до 40\% эффект спекания продолжает возрастать, и прочность образцов достигает 54,3 МПа. Обсуждение. Приведенные результаты показывают, что наиболее активное спекание и формирование плотных структур в грубозернистых композициях с высококальциевым фосфорным шлаком происходит при содержании 40-60\% связки. Наличие плавня вокруг зерен шлака в количестве менее $30 \%$ способствует получению менее плотных образцов, при содержании 40\% связки наблюдается повышение плотности, что соответствует моделированию смешанных структур керамики. Заключение. Для получения высокопрочного керамического кирпича содержание грубодисперсного компонента в виде фосфорного шлака фракции менее 1,25 мм должна составлять 60-70 \%, тонкомолотого фосфорного шлака 5-10\%, бентонитовой глины 20-30\%. Оптимальные технологические показатели: температура обжига 1050-1100ㄷ, давление прессования 20-25 МПа, влажность пресспорошка 7-8\%.
\end{abstract}

КЛЮЧЕВЫЕ СЛОВА: фосфорный шлак, бентонитовая глина, наноструктура, полусухое прессование, пресс-порошок.

для цитИРОвАния: Сулейменов Ж.Т., Сагындыков А.А., Молдамуратов Ж.Н., Баялиева Г.М., Алимбаева Ж.Б. Высокопрочная стеновая керамика на основе фосфорного шлака и бентонитовой глины // Нанотехнологии в строительстве. 2022. Т. 14 , № 1. C. 11-17. https://doi.org/10.15828/2075-8545-2022-14-1-11-17.

\section{ВВЕДЕНИЕ}

$\mathrm{O}$ дним из перспективных строительных материалов с разнообразием цветовой гаммы, фактурой и формой, позволяющим повысить качество облицовки зданий и улучшить архитектурный облик застройки, является керамический кирпич [1-3].

В Казахстане увеличивается спрос на высокомарочные керамические изделия, такие как: клинкерный, фасадный лицевой кирпич. Ограниченность сырьевой базы качественным глинистым сырьем сдерживает производство вышеуказанных эффективных материалов. Основным сырьем для производства керамического кирпича являются суглинки, которые относятся к низкопластичному сырью, с коротким интервалом спекания, не позволяющим получать высокомарочный кирпич. Максимальная прочность изделий из суглинка, обожженного при температуре $1100^{\circ} \mathrm{C}$, не превышает 15 МПа. В этой связи актуальным является переход на полусухой метод прессования с использованием промышленных отходов. Для получения высокопрочных керамических

(с) Сулейменов Ж.Т., Сагындыков А.А., Молдамуратов Ж.Н., Баялиева Г.М., Алимбаева Ж.Б., 2022 

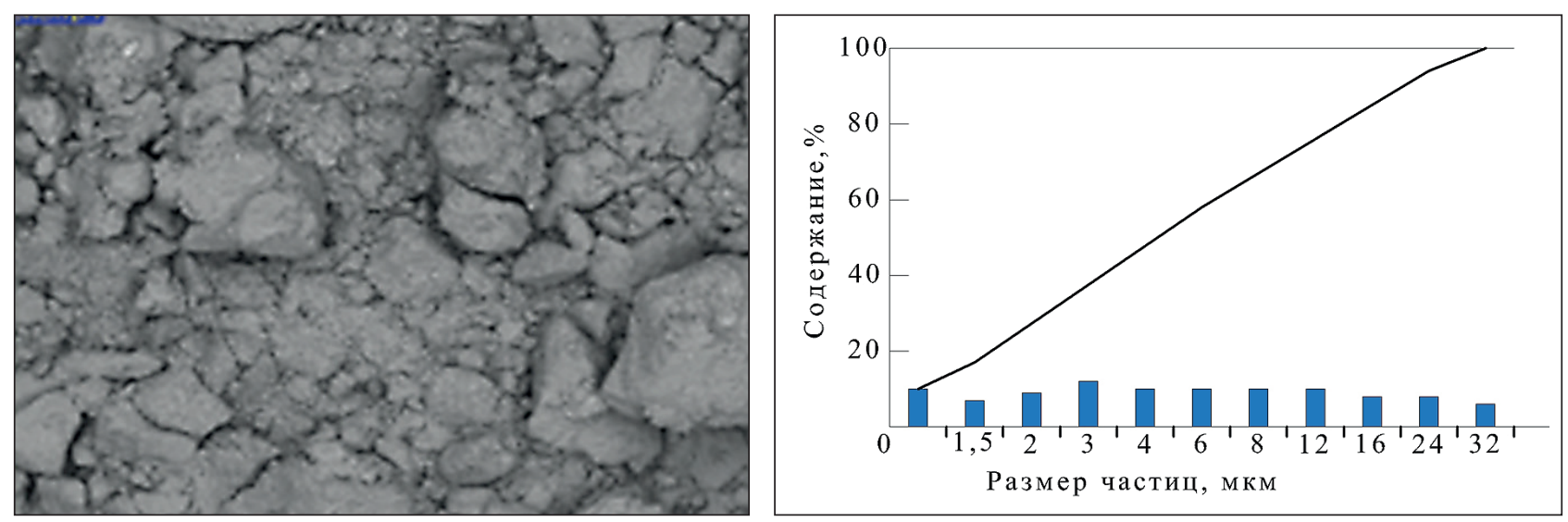

Рис. 1. Микрофотография $(\mathrm{a}, \times 100)$ и распределение частиц бентонитовой глины по размерам (б):

- - распределение по фракциям; — - накопительное распределение

материалов представляет интерес использование композиции по типу «грубодисперсный компонент тонкоизмельченная связка». С такой структурой расход глинистой фракции в составе композиции будет составлять в пределах 25-30\%, а в традиционной керамике пластического формования 75-100\% [4-6].

В настоящее время внимание исследователей в области керамических строительных материалов все больше привлекает применение наноразмерных глинистых связующих [7, 8].

\section{МЕТОДЫ И МАТЕРИАЛЫ}

В качестве пластичного материала для исследуемых керамических масс использовали бентонитовую глину дарбазинского месторождения Туркестанской области, а грубодисперсного материала - плотный закристаллизованный фосфорный шлак.

Бентонит является наноструктурным материалом с высокой удельной поверхностью, обладающей свойством самодиспергации, которая способствует связыванию большого количества непластичного материала. Общеизвестно, что глинистый минерал монтмориллонит состоит из трехэтажных пакетов. Измельченные частицы фосфорного шлака, распо-

Таблица 1

Химический состав сырьевых материалов лагаясь в межпакетном слое монмориллонита, образуют прочные структуры [4, 6, 8, 9].

Определение гранулометрического состава бентонита (рис. 1) показало, что высокодисперсный порошок равномерно распределен по фракциям от 1 до 32 мкм, с преимущественным распределением в интервале от 1 до 12 мкм. Частицы образуют агрегаты неправильной формы [10].

В табл.1 приведен химический состав глины и фосфорного шлака.

Шлак характеризуется повышенным содержанием оксида кальция $(47,5 \%)$, а также наличием пятиоксида фосфора и фтористых соединений до $4,1 \%$, которые обладают флюсующим действием и способствуют снижению температуры обжига керамических материалов. В глине кроме основных оксидов кремния, алюминия, железа присутствуют легкоплавкие оксиды $\mathrm{CaO}, \mathrm{MgO}, \mathrm{Na}_{2} \mathrm{O}$ и $\mathrm{K}_{2} \mathrm{O}$ [11-13].

По числу пластичности (38-40) она относится к высокопластичной, по содержанию глинистых частиц $(62,5 \%)$ - к высокодисперсным, по показателю огнеупорности - к легкоплавким глинам $\left(1250^{\circ} \mathrm{C}\right)$.

Фазовый состав бентонитовой глины характеризуется наличием кварца $(d=0,335 ; 0,425$ нм $)$, иллита $(d=0,319 ; 0,256$ нм), биотита $(d=1,000 ; 0,353$ нм $)$,

\begin{tabular}{|l|c|c|c|c|c|c|c|c|c|c|}
\hline \multirow{2}{*}{ Сырье } & \multicolumn{7}{|c|}{ Состав, масс. \% } & \multicolumn{7}{|c|}{} \\
\cline { 2 - 11 } & $\mathbf{S i O}_{2}$ & $\mathbf{A l}_{2} \mathbf{O}_{3}$ & $\mathbf{F e}_{2} \mathbf{O}_{3}$ & $\mathbf{C a O}$ & $\mathbf{M g O}$ & $\mathbf{N a}_{2} \mathbf{O}$ & $\mathbf{K}_{2} \mathbf{O}$ & $\mathbf{S O}_{3}$ & $\begin{array}{c}\mathbf{F}+ \\
\mathbf{P}_{2} \mathbf{O}_{5}\end{array}$ & $\begin{array}{c}\text { потери прик } \\
\text { проли- } \\
\text { вании }\end{array}$ \\
\hline $\begin{array}{l}\text { Бентонито- } \\
\text { вая глина }\end{array}$ & 60,51 & 16,06 & 6,43 & 1,27 & 2,23 & 2,41 & 2,8 & 1,3 & - & 8,7 \\
\hline $\begin{array}{l}\text { Фосфорный } \\
\text { шлак }\end{array}$ & 41,3 & 2,8 & 0,4 & 47,5 & 1,2 & 0,3 & 0,1 & 0,6 & 4,1 & 0,2 \\
\hline
\end{tabular}


монтмориллонита ( $d=0,950 ; 0,225$ нм), каолинита ( $d=0,709$ нм). Карбонатные включения представлены кальцитом $(d=0,303 ; 0,228$ нм). Также присутствуют калиевый полевой шпат и ферритные фазы. Содержание монтмориллонита составляет 80-85\% [14-16].

Фосфорный шлак Таразского фосфорного завода представляет собой плотную, закристаллизовавшуюся массу, которая плавится при температуре $1320-1350^{\circ} \mathrm{C}$. Фазовый состав фосфорного шлака представлен, главным образом, волластонитом и куспидином [17, 18].

Образцы для стенового керамического кирпича изготавливали следующим образом. Шлак подвергали дроблению и просеву через сито 1,25 мм. Для получения связки шлак и глину подвергали помолу в шаровой мельнице до полного прохождения через сито 0,063 мм. Гранулы шлака размером менее 1,25 мм подвергали увлажнению до достижения влажности 8\%, затем на их поверхность наносили связку. Подготовленный пресс-порошок засыпали в форму и подвергали прессованию при давлении 15-25МПа. Прочность отформованного сырца составляет 0,35-0,4МПа, которая удовлетворяет требованиям работы автомата укладчика. Процесс спекания композиции исследовали на образцах кубах размером 50х50х50мм. Сушку образцов производили при максимальной температуре $105^{\circ} \mathrm{C}$ в течение 3 часов, обжиг осуществляли в муфельной электропечи при температуре $1050-1100^{\circ} \mathrm{C}$ с изотермической выдержкой 30 мин [19-21].

С целью определения оптимального соотношения ядра и оболочки проведено моделирование структур при соотношении 5, 10, 20. Количество вещества оболочки изменялось от 20 до 50\%. Размер агрегатов ядра изменяли от 0,5 до 1,25 мм, толщину оболочки от 0,05 до 0,3мм. Наиболее прочные структуры были получены при соотношении их размеров, равном $10-20$.

В технологии полусухого прессования важно установить максимальные размеры зерен грубодисперсного компонента. Для этого расчитывали температурные напряжения на границах зерен согласно формуле У.Д. Кингери [7]:

$$
\sigma=\frac{1}{3} \cdot \frac{\left(\frac{V_{1} E_{1}}{1-\mu_{1}}\right) \cdot\left(\frac{V_{2} E_{2}}{1-\mu_{2}}\right)}{\left(\frac{V_{1} E_{1}}{1-\mu_{1}}\right) \cdot\left(\frac{V_{2} E_{2}}{1-\mu_{2}}\right)} \cdot \Delta \alpha \cdot \Delta T \cdot d,
$$

где $\sigma$ - напряжение в контактном слое, МПа; $E_{1}$ и $E_{2}-$ модули упругости, МПа; $\mu_{1}, \mu_{2}-$ коэффициенты Пуассона; $\Delta \alpha-$ разность температурного коэффициента линейного расширения фаз; $\Delta T-$ температурный интервал, в котором возникают напряжения; $d$ - размер зерен; $V$ - объемные доли контактирующих фаз.

Из анализа изменения развивающегося на границах зерен термических напряжений были выбраны максимальные размеры зерен шлака (1,25 мм).

Исследования микроструктуры образцов керамики были проведены на сканирующем электронном микроскопе JEOL JSM7500 с приставкой рентгеноспектрального анализа [20].

\section{РЕЗУЛЬТАТЫ}

Изучение влияния рецептурных факторов на основные физико-механические свойства керамических стеновых материалов выполняли методом симплекс - решетчатого планирования экспериментов с использованием в качестве математической модели свойств неполной кубической модели вида [21]:

$$
\begin{aligned}
& Y=A_{1}+A_{2}+A_{3}+A_{4} x y+A_{5} x z+A_{6} y z+ \\
& +A_{7} x y z+A_{8} x y(x-y)+A_{9} x z(x-z)+A_{10} y z(y-z) .
\end{aligned}
$$

В качестве функций отклика Y исследовали предел прочности при сжатии $\left(\mathrm{R}_{\text {сж}}\right)$ и изгибе $\left(\mathrm{R}_{\text {изг }}\right)$, усадку $(\mathrm{U}, \%)$ и водопоглощение $(\mathrm{W}, \%)$.

В качестве сырьевых материалов для получения керамического кирпича были использованы:

$X_{1}$ - содержание фосфорного шлака фракции менее 1,25 мм, 55-70\%;

$X_{2}$ - содержание тонкоизмельченной бентонитовой глины, 25-40\%;

$X_{3}$ - содержание тонкоизмельченного фосфорного шлака, 5-20\%.

Матрица планирования эксперимента приведена в табл. 2.

Фигуративные точки составов связующих на основе шлака и глины находятся в диаграмме состояния $\mathrm{CaO}-\mathrm{Al}_{2} \mathrm{O}_{3}-\mathrm{SiO}_{2}$ и расположены в области треугольника анортит-волластонит-кварц с эвтектикой при температуре $1165^{\circ} \mathrm{C}$.

Уравнение регресии зависимости прочности при сжатии керамического кирпича от состава шихты имеет вид:

$$
\begin{aligned}
& R_{c}=27,1 x_{1}+54,3 x_{2}+49,7 x_{3}-17,1 x_{1} x_{2}+ \\
& +18,225 x_{1} x_{3}-61,875 x_{2} x_{3}+315 x_{1} x_{2}\left(x_{1}-x_{2}\right)+ \\
& +400,275 x_{1} x_{3}\left(x_{1}-x_{3}\right)+282,375 x_{2} x_{3}\left(x_{2}-x_{3}\right)+ \\
& +228,15 x_{1} x_{2} x_{3} .
\end{aligned}
$$

Содержание глины в количестве $25 \%$ гарантирует плотность упаковок, эффект спекания становится достаточным, и прочность образцов составляет 27,1 МПа (рис. 2, в). С увеличением количества глины с 25 до 40\% эффект спекания продолжает возрастать, и прочность образцов достигает 54,3 МПа. 
ПРИМЕНЕНИЕ НАНОМАТЕРИАЛОВ И НАНОТЕХНОЛОГИЙ В СТРОИТЕЛЬСТВЕ

Таблиия 2

Матрица планирования эксперимента

\begin{tabular}{|c|c|c|c|c|c|c|c|}
\hline \multirow{3}{*}{$\begin{array}{c}\text { № } \\
\text { состава }\end{array}$} & \multicolumn{3}{|c|}{ Содержание компонентов, $\%$} & \multicolumn{4}{|c|}{ Свойства } \\
\hline & $\begin{array}{c}\text { Фосфорный шлак } \\
\text { фракции менее } \\
1,25 \text { мм, \% }\end{array}$ & $\begin{array}{c}\text { Бентонитовая } \\
\text { глина, \% }\end{array}$ & $\begin{array}{c}\text { Фосфорный } \\
\text { шлак тонко } \\
\text { измельченный, \% }\end{array}$ & \multirow[t]{2}{*}{$\mathbf{U}, \%$} & \multirow[t]{2}{*}{$\begin{array}{l}\mathbf{R}_{\text {сж}} \\
\text { МПа }\end{array}$} & \multirow[t]{2}{*}{$\begin{array}{l}\mathbf{R}_{\text {изг }} \\
\text { МПа }\end{array}$} & \multirow[t]{2}{*}{$\mathrm{W}, \%$} \\
\hline & $X_{1}$ & $X_{2}$ & $X_{3}$ & & & & \\
\hline 1 & 70 & 25 & 5 & 0,9 & 26,1 & 2,8 & 13,8 \\
\hline 2 & 55 & 40 & 5 & 1,9 & 54,3 & 4,7 & 5,2 \\
\hline 3 & 55 & 25 & 20 & 1,6 & 36,7 & 3,6 & 8,2 \\
\hline 4 & 65 & 30 & 5 & 1,2 & 32,3 & 3,4 & 11,8 \\
\hline 5 & 60 & 35 & 5 & 1,6 & 51,5 & 3,7 & 10,4 \\
\hline 6 & 65 & 25 & 10 & 1,4 & 30,8 & 3,2 & 11,8 \\
\hline 7 & 60 & 25 & 15 & 1,5 & 34,7 & 3,7 & 11,2 \\
\hline 8 & 55 & 35 & 10 & 1,1 & 45,3 & 3,6 & 7,4 \\
\hline 9 & 55 & 30 & 15 & 1,2 & 38,6 & 3,7 & 8,6 \\
\hline 10 & 60 & 30 & 10 & 1,4 & 43,4 & 3,9 & 10,9 \\
\hline
\end{tabular}

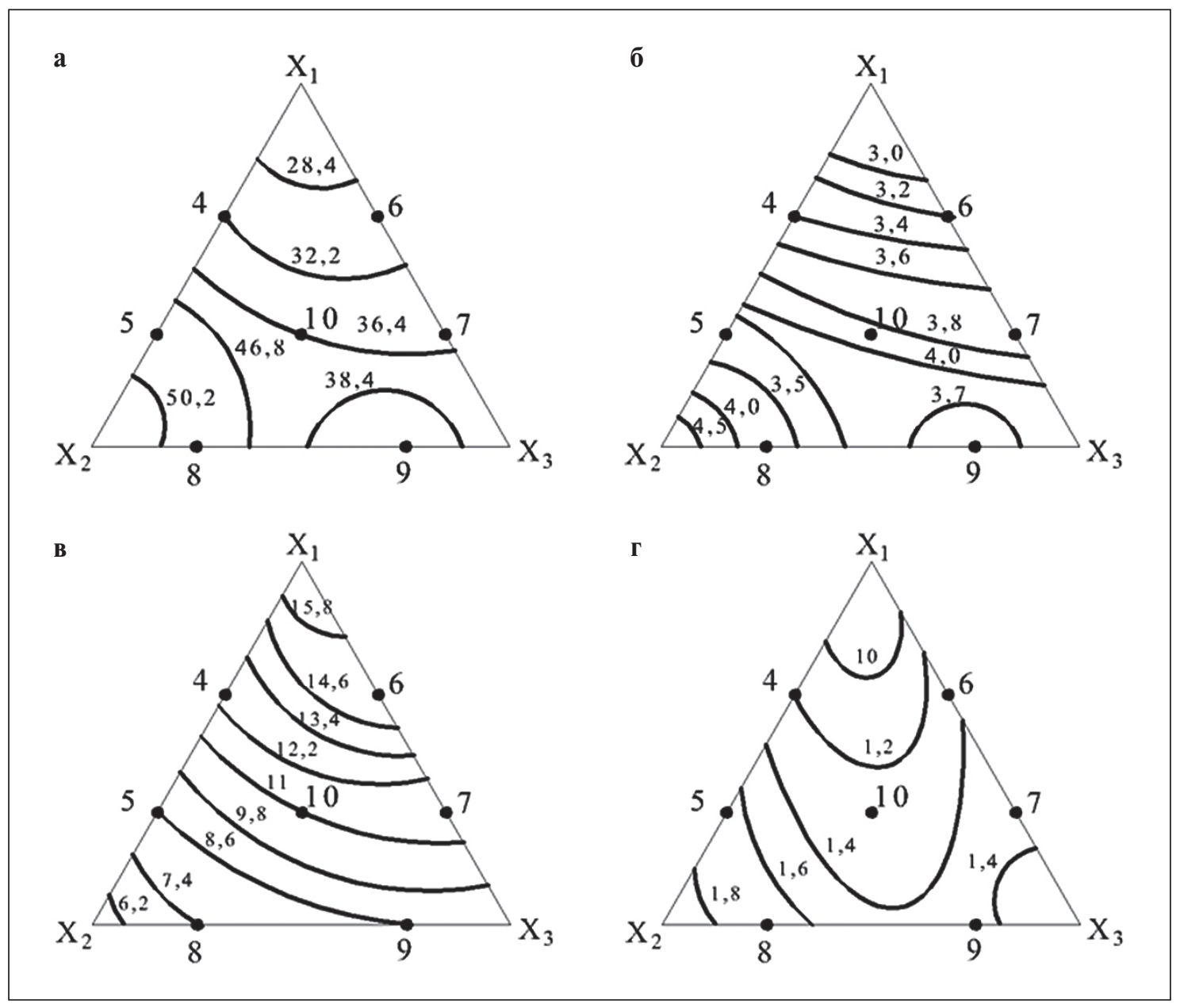

Рис. 2. Линии равных значений изменения свойств высокопрочной керамики: а - предел прочности при сжатии; б - предел прочности изгибе; в - водопоглощение; г - усадка 
Согласно полученным диаграммам «составсвойство» (рис. 2 а, б, в, г), керамические кирпичи имеют малую усадку $(0,9-1,6 \%)$, водопоглощение $(7,4-12,1 \%)$, высокий показатель прочности при изгибе (2,8-4,7 МПа).

\section{ОБСУЖДЕНИЕ}

Полученные результаты показывают, что наиболее активное спекание и формирование плотных структур в грубозернистых композициях с высококальциевым шлаком происходит при содержании $35-45 \%$ связки и соотношений ядра и оболочки 10-20 в соответствии с моделированием смешанных структур керамики [17-19].

Согласно термодинамическим расчетам в процессе обжига в температурах 400,800 и $1000^{\circ} \mathrm{C}$ наиболее вероятно образование анортита $\left(\mathrm{CaO} \mathrm{Al}_{2} \mathrm{O}_{3} 2 \mathrm{SiO}_{2}\right)$, кварца и волластонита, т.е. фаз с наибольшими отрицательными значениями свободной энергии Гибсса $(\Delta \mathrm{Z})$, не изменяющимися плотностями в процессе синтеза и способствующими увеличению прочности кирпича.

Создание каркасной структуры было обеспечено за счет применения полифракционного состава (фосфорного шлака) и связки из тонкомолотых бентонита и фосфорного шлака.

На рис. 3 приведены модели каркасной структуры составных элементов (кристаллического каркаса и связки) материала.

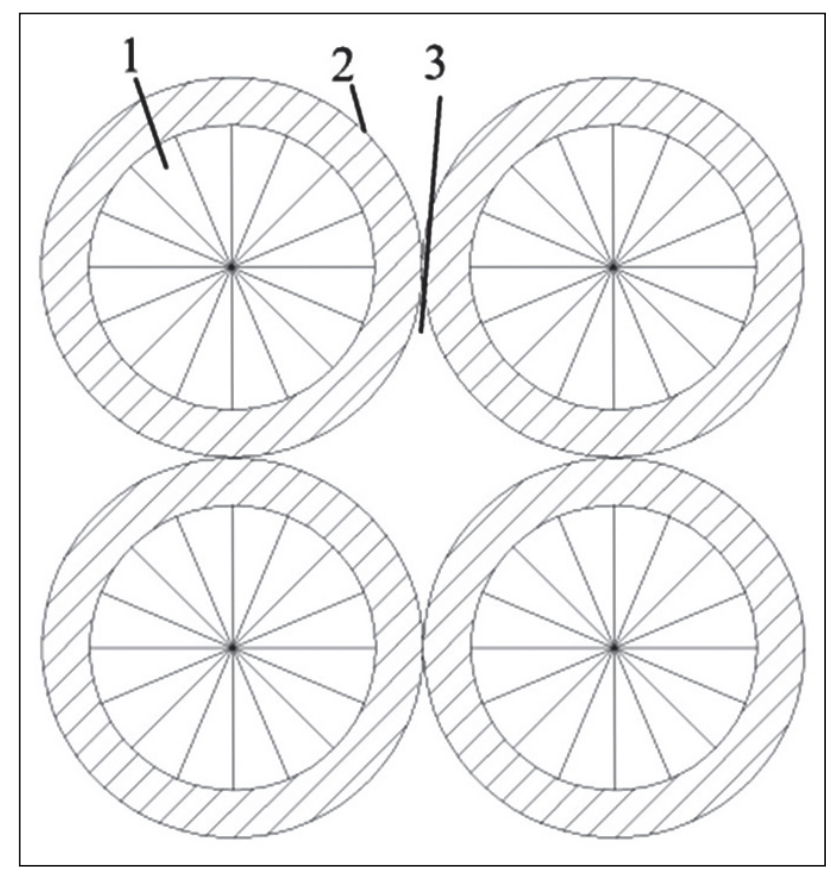

Структура образцов из композиций зернистого шлака со связками является наиболее ярко выраженным вариантом структур по типу «ядро - оболочка» (рис. 4 а, б). А характер структур шлака со связками наиболее четко отражает процесс их формирования. По структуре образцов видно, что связка образует оболочки вокруг крупных и расположенных между ними средних и мелких зерен шлака. Видно, что оболочки взаимодействуют с поверхностью зерен с образованием кристаллических фаз волластонита и анортита. Взаимодействие оболочки с зерном протекает очень активно, от поверхности зерна шлака к оболочке образуется достаточно заметная переходная зона как результат этого взаимодействия. Образование переходной зоны обуславливает согласованность шлакового зерна с оболочкой. Поэтому прочность образцов высокая и составляет 49-54,3 МПа при сжатии и 4,3-4,7 МПа при изгибе [15].

Из структуры плотно спеченных образцов, достигнутой использованием максимального (40\%) количества глины в связке и после обжига при более высокой температуре $\left(1050-1100^{\circ} \mathrm{C}\right)$, видно, что мельчайшие зерна шлака вовлекаются в процесс образования жидкой фазы. Повышается количество и реакционная способность стеклофазы за счет влияния фторсодержащих компонентов шлака. Это выражается в увеличении толщины промежуточной зоны от поверхности крупных зерен шлака к оболочкам вокруг них, в активизации

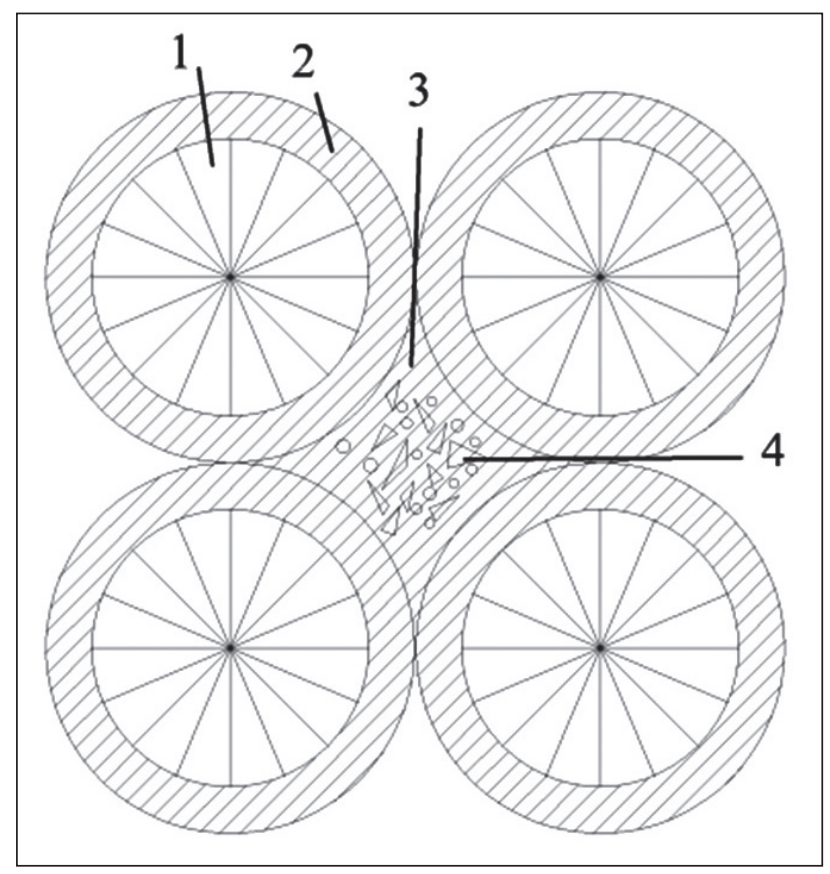

Рис. 3. Модель каркасной структуры керамических материалов по типу «ядро - оболочка»:

1 - гранула шлака; 2 - связующее; 3 - поры; 4 - связующее и кристаллы волластонита и анортита 

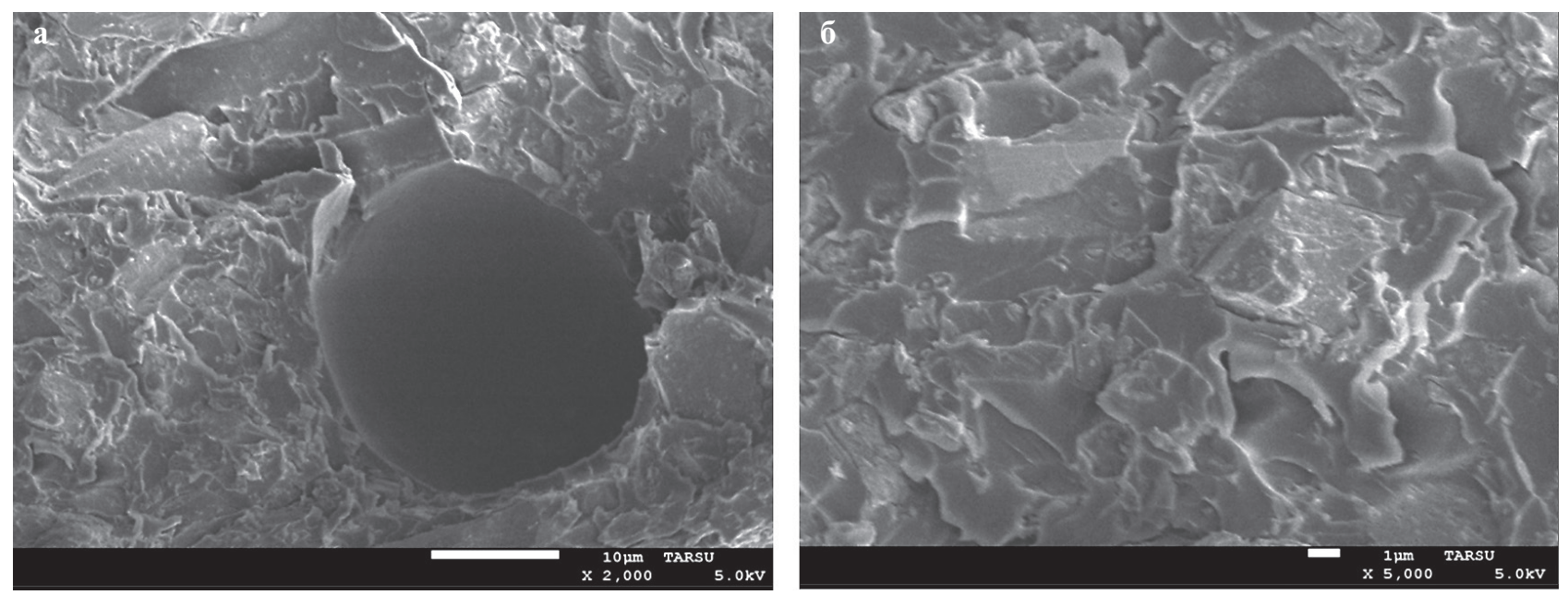

Рис. 4. Микроструктура керамики из композиции фосфорного шлака и бентонитовой глины: а - температура обжига $1050^{\circ} \mathrm{C} ;$ б - температура обжига $1100^{\circ} \mathrm{C}$

кристаллизации новых фаз в виде волластонита и анортита в оболочке. Кроме того, понижение вязкости стеклофазы за счет кальциевых ионов, увеличение ее проникающей способности и сродство стеклофазы с зернами шлака способствуют ее растеканию по поверхности образцов и образованию стекловидного покрытия, которое при охлаждении кристаллизуется [14].

По краям зерен шлака и между ними, а также на их поверхности наблюдаются продукты взаимодействия.

\section{ЗАКЛЮЧЕНИЕ}

Для получения высокопрочного керамического кирпича содержание грубодисперсного компонента в виде фосфорного шлака фракции менее 1,25 мм должно составлять 55-65\%, тонкомолотого фосфорного шлака - 5-10\%, бентонитовой глины 30-40\%. Оптимальные технологические показатели: температура обжига $-1050-1100^{\circ} \mathrm{C}$, давление прессования - 20-25 МПа, влажность пресспорошка $7-8 \%$.

\section{СПИСОК ИСТОЧНИКОВ}

1. Suvorova O V., Selivanova EA, Mikhailova JA, Masloboev VA, Makarov D V. (2020) Ceramic products from mining and metallurgical waste. Appl Sci. https://doi.org/10.3390/app10103515

2. Poznyak AI, Levitskii IA, Barantseva SE (2012) Production of interior facing tiles using local raw materials. Glas Ceram (English Transl Steklo i Keramika) 69:77-80

3. de Figueirêdo JMR, Sousa Silva JR, de Araújo Neves G, Ferreira HC, de Lima Santana LN (2019) Influence of processing variables on clay-based ceramic formulations. Mater Res. https://doi.org/10.1590/1980-5373-MR-2018-0548

4. Kadyrova ZR, Purkhanatdinov AP, Niyazova SM (2020) Research of benonite clays of Karakalpakstan for producing ceramic heat-insulating materials. NOVYE OGNEUPORY (NEW Refract. https://doi.org/10.17073/1683-4518-2020-9-4-7

5. Chetverikova A.G., Kanygina O.N., Alpysbaeva G.Z., Yudin A.A., Sokabayeva S.S. Infrared spectroscopy as the method for determining structural responses of natural clays to microwave exposure. Condensed Matter and Interphases. $2019 ; 21$ (3): $446-454$.

6. Asal S, Erenturk SA, Haciyakupoglu S (2021) Bentonite based ceramic materials from a perspective of gamma-ray shielding: Preparation, characterization and performance evaluation. Nucl Eng Technol. https://doi.org/10.1016/j.net.2020.11.009

7. Montayev S, Shakeshev B, Zharylgapov S (2020) Development of a technology for producing ceramic refractory material in a composition of montmorillonite clays (bentonite-like) and ferrochrome production wastes. MATEC Web Conf. https://doi. org/10.1051/matecconf/202031507007

8. (2020) Karakalpakstan Bentonite Clays - Perspective Raw Materials for Obtaining Ceramic Heat-Insulating Materials. Int J Innov Technol Explor Eng. https://doi.org/10.35940/ijitee.f3821.069820

9. Erdogan Y, Kok OE (2019) Prodfction and characterization of nanobentonite from Sodifm bentonite with mechanical grinding. Fresenius Environ. Bull. 28: 
10. Kadyrova ZR, Purkhanatdinov AP, Niyazova SM (2021) Study of Karakalpakstan Bentonite Clay for Producing Ceramic Heat-Insulating Materials. Refract Ind Ceram. https://doi.org/10.1007/s11148-021-00528-1

11. Ngoc Lam N (2020) Eco - Concrete made with phosphogypsum-based super sulfated cement. IOP Conf Ser Mater Sci Eng. https://doi.org/10.1088/1757-899X/869/3/032031

12. Nguyen VH, Nguyen VC, Nguyen TC, Tran DMT, Nguyen TTT, Vu QT, Nguyen DT, Thai H (2020) Treatment of Yellow Phosphorus Slag and Reuse of It as an Absorbent of Chromium (VI) Ions and Methylene Blue. J Chem. https://doi. org/10.1155/2020/1834829

13. Garbaya H, Jraba A, Khadimallah MA, Elaloui E (2021) The Development of a New Phosphogypsum-Based Construction Material: A Study of the Physicochemical, Mechanical and Thermal Characteristics. Materials (Basel). https://doi.org/10.3390/ $\underline{\text { ma14237369 }}$

14. Djobo JNY, Stephan D (2021) Control of the setting reaction and strength development of slag-blended volcanic ash-based phosphate geopolymer with the addition of boric acid. J Aust Ceram Soc. https://doi.org/10.1007/s41779-021-00610-4

15. Najimi M, Ghafoori N, Sharbaf M (2020) Alkali-activated natural pozzolan/slag binders: Limitations and remediation. Mag Concr Res. https://doi.org/10.1680/jmacr.18.00184

16. Sarsenbayev NB, Kurbaniyazov SK, Saktaganova NA, Karshygayev RO (2020) The influence of additives of dehydrated clay on the properties of unburned binders and concrete on their basis. IOP Conf Ser Mater Sci Eng. https://doi.org/10.1088/1757$\underline{899 X / 945 / 1 / 012048}$

17. Kenzhaliyev BK, Surkova TY, Abdikerim BE, Berkinbayeva AN, Abikak YB, Yessimova DM (2022) Research on sorption properties of phosphoric production slag-waste. Metalurgija 61:

18. Tian X, Zhang Y, Zhao F (2021) Mechanism of steel slag-phosphoric acid system regulating the setting performance of phosphogypsum based building gypsum. Huagong Jinzhan/Chemical Ind Eng Prog. https://doi.org/10.16085/j.issn.1000-6613.2020-2019

19. Вернер ВФ, Худякова ТМ, Сарсенбаев БК, Шакей АM, Сауганова ГР (2021) PRODUCTION OF SYNTHETIC WOLLASTONITE BASED ON PHOSPHORIC SLAG AND AMORPHOUS SILICA PRODUCED BY “SOLAR” SILICON. https://doi.org/10.34708/gstou.conf..2021.54.99.031

20. Gao P, Lu X, Yang C, Li X, Shi N, Jin S (2008) Microstructure and pore structure of concrete mixed with superfine phosphorous slag and superplasticizer. Constr Build Mater. https://doi.org/10.1016/j.conbuildmat.2006.12.015

21. Suleimenov ZT, Sagyndykov AA, Kirgizbaev AT (2016) Ceramic Face Tiles Using Phosphoric Slags. Glas Ceram (English Transl Steklo i Keramika). https://doi.org/10.1007/s10717-016-9826-7

\section{ИНФОРМАЦИЯ ОБ АВТОРАХ}

Сулейменов Жусупбек Таширбаевич - доктор технических наук, академик НАН РК, профессор кафедры «Строительство и производство материалов», Таразский региональный университет имени M.X. Дулати, Тараз, Казахстан, ernur.abutalipov98@mail.ru, https://orcid.org/00000002-1431-8074

Сагындыков Аймахамбет Абуталипович - доктор технических наук, профессор кафедры «Строительство и производство материалов», Таразский региональный университет имени М.Х. Дулати, Тараз, Казахстан, ernur.abutalipov98@mail.ru, https://orcid.org/0000-0002-1812-5739 Молдамуратов Жангазы Нуржанович - PhD, доцент, заведующий кафедрой «Строительство и производство материалов», Таразский региональный университет имени М.Х. Дулати, Тараз, Казахстан, zhanga_m_n@mail.ru, https://orcid.org/0000-0002-4573-1179

Баялиева Гульсара Муратовна - кандидат технических наук, доцент кафедры «Строительство и производство материалов», Таразский региональный университет имени М.Х. Дулати, Тараз, Казахстан, bayali@bk.ru, https://orcid.org/0000-0002-9897-5740

Алимбаева Жанна Базартаевна - инженер кафедры «Строительство и производство материалов», Таразский региональный университет имени М.X. Дулати, Тараз, Казахстан, alimbayeva.zhanna08@mail.ru, https://orcid.org/0000-0001-9372-4101

\section{ВКЛАД АВТОРОВ}

Сулейменов Ж.т. - научное руководство; концепция исследования; развитие методологии; научное редактирование текста; итоговые выводы. Сагындыков А.А. - концепция исследования; развитие методологии; проведение экспериментальной работы; обработка экспериментальных данных; сбор материала; написание исходного текста; итоговые выводы.

Молдамуратов Ж.Н. - написание исходного текста; итоговые выводы.

Баялиева Г.М. - проведение экспериментальной работы; обработка экспериментальных данных; написание исходного текста; работа с редакцией журнала.

Алимбаева Ж.Б. - проведение экспериментальной работы; обработка экспериментальных данных; сбор материала.

\section{Авторы заявляют об отсутствии конфликта интересов.}

Статья поступила в редакцию 24.01.2022; одобрена после рецензирования 07.02.2022; принята к публикации 09.02.2022. 